\title{
Ethno-religious hate speeches and political violence in Nigeria's fourth republic
}

\author{
Ugo Chuks Okolie \\ Chartered Institute of Personnel Management of Nigeria, Ikeja, Nigeria; \\ Edo State Study Centre, Benin City, Nigeria \\ Eseohe Glory Okoedion
}

\section{University of Nigeria, Nsukka, Nigeria}

Ethno- religious hate speech is the precursor to political violence in Nigeria's fourth republic. While it is true that one of the greatest benefits of democratic societies is freedom of speech, still no one should be allowed under the disguise of exercising the right to free speech to offend, humiliate and demean another human being. In Nigeria, hate speech has been elevated to the status of political campaign strategy and it accounts for the escalation of political violence in Nigeria's fourth republic. Therefore, this study explored the impact of ethno-religious hate speech on political violence in Nigeria's fourth public. A descriptive method was adopted and data was collected via a survey of 600 electorates in South-South zone of Nigeria. The study found that there is a positive and significant relationship between Ethno-religious hate speech and political violence in Nigeria's fourth republic. This paper recommends among others that political campaign in Nigeria should focus on the implementation of the critical national issues such as economic, political, social, cultural, educational, and healthcare services rather than attack on political opponents or mobilization of ethnic, religious, and regional sentiments. Nigeria

Keywords: hate speech, political violence, political campaign, ethno-religious groups,

\section{Introduction}

Ethno-religious hate speech in Nigeria's fourth republic has been characterized by violent outbursts by public officials, academia, and is demonstrated in several exchanges on the streets, online forums, and in sectarian print media in different parts of the country. Nigeria is a very diverse country in terms of ethnic

(C) Okolie U.C., Okoedion E.G., 2019

This work is licensed under a Creative Commons Attribution 4.0 International License https://creativecommons.org/licenses/by/4.0/ 
orientations, cultural practices, religious beliefs, and linguistics. These differences have been a source of tension beginning from the colonial era under British rule (Joel, 2013). However, its current manifestations are rapidly dividing the country into pockets of religious and ethnic cleavages. One of the main caveats of modern democratic societies everywhere in the world is the right to free speech. This means that people are inherently entitled to expressing their opinions regarding all aspects of life. However, as the waves of hateful, demeaning, and dehumanizing messages against particular individuals, or groups of individuals on the grounds of their political affiliation, religious conviction, ethnicity, sexual orientation, disability, etc., intensity and expand in proportion to the human race, it becomes highly debatable whether hate speech should be considered simply as freedom of speech.

In Nigeria particularly, the effects of political activities which show hate speech have become more vivid in the successive democratic dispensation than the previous years. The deeds of politicians have amplified the situation negatively and keeping the citizens more divided now than ever before signals a great source of anxiety to Nigerians at home and in the Diaspora. Political leader in Nigeria use hate speech to divide and rule the people already divided along ethnic and religious lines and this incites co-existing ethnic and religious groups, thereby generating all forms of violence especially political related ones. Though, the challenges of hate speech cut across all countries. For instance, the 2016 presidential election in the United States was a fertile ground for hate speech and up till this day, long after the election was won and lost, the American society remains divided on account of the unparalleled hate speech that attended the election. Specifically in Nigeria, hate speech is thick in the air $[27 ; 31]$.

Political violence has been part of human history, present in the history of all humanity for ages. It is an endemic feature of most of the developing world political systems. Particularly in developing countries, like Nigeria, where politics has become an essential feature of the people means of achieving economic wealth [28; 4]. It was Nigeria's pride that she achieved her independence with minimum disturbance, but is rather unfortunate that after independence, Nigeria has been gravitating in a spiral of political violence. The continued eruptions of political violence have implications for national peace and security, and thereby threaten the dissolution of the country Nigeria (Onwubike, 2013). Therefore, political violence negates peaceful co-existence, law and order. In addition to security concerns, political violence militates against the consolidation of democracy and social co-existence. This in turn impact on the social and economic well-being of the nation and creates imbalances in social relations [13;7].

Ethno-religious hate speech and political violence are rising and the country is daily challenged by these forces. Ethno-religious hate speeches define the people's daily lives. Yoruba, Igbo, Huasa, Kanuri, Ijaw, Efik, Ibibio and the over 250 ethnic nationalities that make up the entity called Nigeria all have hate tags for one another. In spite of this, there has been no official response or policy to ban hate speech in Nigeria, although there are laws against slander and perjury (Joel, 2013). Although extant literature agrees that political violence are caused by many fac- 
tors which include lack of internal democratic structures and processes within the individual political parties-leading to imposition of candidates on party members; weak democratic institutions and culture; the prevailing political mind-set of do-or die and winner takes-all; the lack of prompt judicial response to cases of electoral offence; and the general socio economic downturn that has rather remained unaddressed over the years, they have not satisfactorily examined the impact of ethnoreligious hate speech on political violence in Nigeria's fourth republic. This study therefore, seeks to examine the relationship between ethno-religious hate speech and political violence in Nigeria's fourth republic and provide requisite recommendations and conclusion in the light of empirical and theoretical findings.

\section{Statement of Problem}

Historically, Nigeria has organized five general elections and many state or local government elections between 1999 and 2015. A review of these elections revealed that Nigeria has witnessed both election and political violence. Political class continues to arm the youths, employ and deploy them to commit heinous crimes, shed blood at every critical point in our political life especially during election era; water the streets with blood of the youths themselves, innocent by-stands passersby. The politicians themselves are assassinated in broad day and in cold blood; and wantonly destroyed in the Manichean guest for political power. The society and the political system are caught in a spider web or maelstrom of violence and death. Political violence in Nigeria manifest in acrimony, assault, assignation, intimidation, harassment, maiming and killing. Consequently, these affect the existing social relationship in the society. Politicians in Nigeria usually deviate from presenting their manifestoes to the people to delivering hate speeches against their opponent-personality, political parties, ethnic backgrounds and religious. These hate speeches have been pointed out as one of the major causes of political violence in the country. The role of hate speech in political violence has been established in Arica. Most notable examples are the 2007 post electoral violence in Kenya, and the 2003, 2007 and 2011 post electoral violence in Nigeria [25; 10]. Therefore, the seed of ethno-religious hate speech/campaign has matured in Africa but the phenomenon is largely understudied and underreported. Although these independents but related studies were apt and scientific, none of them examined the effect of ethnoreligious hate speech on political violence in Nigeria from 2003-2018. Therefore, this study seeks to fill this gap as it takes a critical look at the relationship between ethno-religious hate speech and political violence in Nigeria's fourth republic.

\section{Objectives of the Study}

This study specifically identified the following objectives:

1) to examined the nature of ethno-religious hate speech and political violence in Nigeria's fourth republic;

2) to examined the relationship between ethno-religious speech and political violence in Nigeria's fourth republic. 


\section{Research Hypothesis}

The null hypothesis was formulated for testing:

Ho: there is no significant relationship between ethno-religious hate speech and political violence in Nigeria's fourth republic.

\section{Literature Review}

Ethno-Religious Hate Speech. The idea of 'hate speech' in Nigeria is still new and is yet to acquire wide spread acceptance or recognition. It is usually subsumed under discourse on ethno-centrism and religious intolerance. For a nation with widespread ethnic and religious intolerance; it is very easy for hate speech to go unreported, unrestrained, and unchallenged. Ethno-religious hate speech refers to ethnic slur towards members of an out-group (Mossoro 1991). Also, Leader, Mullen and Rice [18] view ethno-religious hate speech as hostility and hatred towards members of an out-group. It is this sense of differentiated identity between ethnic groups that lie at the core of this form of hate speech in Nigeria. This hostility is expressed in name-calling of a virulent and base nature. It is common to hear Hausa's being referred to as 'Malo', a derogative term that can be loosely translated as 'mentally unstable'. Intense hostility is reflected in the interlocution of namecalling (Joel, 2013). Therefore, ethnic labels promote hostility and rejective behaviours, which becomes fodder for ethnic rivalry and violence.

Hate speech is any speech that attacks a person or group on the basis of attributes a such as gender, ethnic, origin, religion, race, disability, or sexual orientation [11]. In the view of Bagdikian [5], hate speech is a communication that employs intolerant appellations to insult and denounce others either on the basis of their race, religion, ethnicity, gender, or other forms of group membership. Hate speech is considered as any speech, gesture, conduct, writing or display, which could incite people to violence or prejudicial action. Evidently, hate speech is bound to appear whenever someone feels the urge to demean and demonize those holding opposing views, as well as when one wishes to persuade or rather manipulate other people into accepting and endorsing a particular ideology in other to achieve certain political and social goals [23].

The nature and characteristics of ethno-religious hate speech in Nigeria makes the use of legal regulations unsuitable. Moreover, due to the endemic nature of the act both in offline spaces and online forums such as Twitter, Facebook, YouTube, Instagram, etc., a regulation restricting internet access or proscribing hate speech online will be difficult to implement in a politically fractured nation as Nigeria. Indeed, phenomenon of hate speech has taken as extensive dimension in Africa due to poor regulations. In Nigeria, it has become an important aspect of electioneering campaign today that numerous election related conflict are credited to hate speech. Observably, hate speech has eaten deep into the bone marrows of Nigerians and it has continued unabated [10]. The hatred between the ethnic groups that make up Nigeria has intensified as the use of hate speech continues unregulated. This hatred 
manifests mostly between the dominant ethnic groups (Igbos, Yorubas \& Hausas). Hence, there is an urgent need for broad-based co-operation between government agencies, media houses, and civil society to challenge ethno-religious hate speech in Nigeria.

Consequently, ethno-religious hate speech exemplified rhetorical strategies which drive some people to a level of hostility in which they openly wish physical harm on others or political leaders, contravening vital norms that enable democratic government to function [8]. Consequences of ethno-religious hate speech in Nigeria are widely obvious, from diatribes on social media to ethnic violence in the Jos, Pleateu State and other regions in Northern Nigeria. Rasaq et al. [27] posit that hate speech lead to lower personal self-esteem and a diminished sense of security. Leets [19] concludes that hate speech violates the individual's dignity, resulting in humiliation, distress and psychological or emotional pain. Similarly, Judge [16] and Nel (2018) affirm that hate speech can provoke pain, distress fear, embarrassment and isolation to individuals. While hate speech towards group of people can bring inequalities, problems and isolation, it creates the feeling of fear and discourages them from participating in the community and expressing their opinions [17]. Adding to the argument, Bell [6] holds that hate speech is worse than discriminatory speech. It use traditional epithets or symbols of derision to vilify on the basis of group membership expresses contempt for its targets and seems more likely to cause emotional distress and to provoke visceral, rather than articulate response. Therefore, ethno-religious hate speech incite hatred, terrorism, and genocide.

As regards motivation of ethno-religious hate speech, Alakali, Faga and Mbursa [2] pointed out several factors such as lack of tolerance, political clashes, discrimination, enmity, and the openness of social media as motivating hate speech online. It is clear that there are many old underlying issues that exploded in the post-election violence in Nigeria that longs been neglected by the political leaders; which confuses calm for peace, inactivity for stability. Some of these issues include long held ethnic tensions that have roots in political, economic and social dialectics; impurity for massive human rights violations; corruption; and security forces that are corrupt, oppressive and used for partisan political purposes rather than for maintaining security and combating crime.

Political Violence. Political violence is a determinant of armed conflict, complex interplay of ideology, quest for power by competing groups, specific in the country and international conditions. It is - an extreme or repressive measure that has threatened the rule of law, personal freedoms and human rights. The economic determinants of violence, in turn, are often related to poverty, inequality, and social exclusion [4]. According to Wolff (2006:3), violence is defines as 'the illegitimate and unauthorized use of force to effect decisions against the will or desires of the other people in the society'. In the view of Uhunmwuangho and Epelle (2011), violence denotes employment of illegal methods or physical coercion for personal or group ends. Violence is also view as the means through which thugs achieve their aims. Therefore, violence is ascribed to outlaws and thugs who unleash terror on the law-abiding citizens and cause social and political instability in the society. 
According to Gurr [12], political violence refers to all collective attacks within a political community against the political regime, its actors including competing political groups as well as incumbents or its policies. Alemika (2011) posits that violence, particularly political violence, represents a disturbance movement to the political equilibrium and peaceful coexistence of the system. The Nigerian political scene is bedeviled by violence. This can be attributed to the culture of political activity during the pre-independence period and the early stage of political independence in 1996. Therefore, political violence as a means to propagate and maintain the status quo in Nigeria is historical and structural in nature. It has been with us since the early independence years and was deployed by the existing political parties then. In addition, the 2011 general election marked another ugly milestone of political violence in the political history and culture in Nigeria. Comparatively, it is rather difficult to determine which of the most violence afflicted general elections were since the return to civil rule in mid-1999. The 1999 general election was violent prone; so also was the 2013, 2007, and 2011 general election. The number of deaths recorded increases after each general election since 1999 [7]. The continually deteriorating economic conditions continue to throw up new dynamics and nuances which alter the pattern of political violence in Nigeria. For instance, bombing was non-existent in 1999, 2003 and 2007 general elections. Thus, the specificity of terrorism is new phenomenon of political violence in Nigeria.

Scholars such as Joel (2013); Ezeibe [10]; Fasakin et al. [11]; Resaq et al. (2017) have argued that the immediate causes of political violence in Nigeria in both the current as well as past political dispensation include hate speech and foul language, lack of internal democratic structures and processes within the individual political parties, youth's unemployment, prevailing political mind-set of do or die and winner takes-all, misinterpretation of religious tenets, weak democratic institutions and culture, lack of prompt judicial response to cases of electoral offences, imposition of candidates on party members, the weakness and alleged partisanship of the law enforcement agencies during election times, ethnic and religious intolerance, the general socio-economic downturn that has rather remained unaddressed over the years, bad governance, and fanaticism/bigotry. All these have posed a number of threats to the legitimacy of the national government and its ability to offer leadership appropriate to the demand of nation-building.

\section{Ethno-Religious Hate Speech and Political Violence in Nigeria's Fourth}

Republic. Nigeria is one of the nations in the world whose political landscape has been inundated, suffused with and deeply enmeshed in spectrum of recurring complex conflicts ranging from resource, communal, to ethno-religious and political conflicts. In Nigeria, political and ethno-religious conflagrations has become highly disruptive to social life, thereby causing divisions in families and communities as well as causing antagonisms among and within social groups. Nigerians have witnessed several cases of political violence in the form of assassinations, bombblasts, intimidation, murders, and destruction of properties in time past and now on the increase. The political activities in Nigeria since the inception of the Fourth Republic in 1999 till the present-day, have witnessed tremendous degrees of power 
struggle and political violence whereby the number of politically motivated murders is said to be equal to the number of people killed during the Nigerian Civil War in 1967 to 1970 [4;11].

Nigeria's history, its diversity and political landscape makes it susceptible to ethnic and religious intolerance, which feeds into hate speech. An interesting fact about hate speech in Nigeria is the absence of a set of aggressor and victims. In different frontiers, these roles shift depending on the part of the country an individual hail from and reside in. while the Northern manifestations of intolerance and hate speech are often accompanied by violent acts, in the south, it is more subtle. Here, hate speech are often manifested more in stereotyping and abusive denotation of mannerisms of other ethnic groups, particularly Northerners. While it can be argued that there exist stereotypes about every ethnic group, the vitriol and violence that pervades its manifestations between Northern and southern Nigeria is unequalled. Also, ethnic intolerance plays out in relationships between Northern Muslims and Muslims in Southern Nigeria. For instance, in Lagos, Akure, Ibadan, Ijebu-ode etc., Muslims are quite liberal and it is not uncommon to find coupled practicing different religious. Almost every family has members practicing either of the two religious. This has been widely criticized by the Northern Muslims who are not as liberal not as Southern. It has been reported that Southern Muslims are not real Mulims [20]. Moreover, ethno-religious intolerance and hate speech is so pervasive in Nigeria that is sometimes difficult to identify or classify, especially when it is delivered as a form of comedy routine, in book publications, and social media (Joel, 2013).

Political violence geared towards winning political competition or power through violence, subverting the ends of the electoral and democratic process is very pervasive in Nigeria. Mrabure [21] noted that politically motivated hate speech is generally an antecedent to election related provocation and violence is Nigeria. Essentially, such speeches rob others of their dignity. In spite of the Nigeria Electoral Act 2010 which spells out detailed provisions specifically barring politically inspired hateful speech, still cases of offensive images of major aspirants, in an effort to create a strong picture of a bad person flourish and have been described by Nigerians as 'one step too far' [27]. The 2015 general elections in Nigeria, like other elections, have come and gone but the different events and issues surrounding the elections cannot be ignored by analysts, observers and scholars. The campaign period of the elections saw many hate speeches being used by politicians in the country. Most of these derogatory speeches and advertorials were used by the members of the two leading political parties in the country the People Democratic Party (PDP) and All People's Congress (APC). Ethno-religious hate speech and political violence have severally drawn the country to the precipice of disaster. It has engendered huge human carnage, internal displacements and refugee crises, loss of investments, strained inter-communal or inter-ethnic relations, threatened internal security and public order. There is the high level of inter-ethnic and inter-religious vendetta in the country, to the point that it seems that Nigeria is now exhibiting the symptom of a collapsing state, whose members are perpetually at war with one another [14]. 
There are several cases of ethno-religious hate speech in Nigeria. A classic case will be that of General Muhammadu Buhari, a former presidential candidate of Congress for Progressive Change who threatened president Goodluck Jonathan to avoid using his power of incumbency to rig the 2015 presidential election or something will happen (apparently, a repeat of 2011 post -election violence). Again, the utterance of Shema Ibrahim of Kastina State (An APC Chieftain) which referred members of the opposition political party (PDP, Labor Party and others) as cockroaches was one of the deadliest hate speeches in Nigeria. He encouraged members of his party to crush (kill) members of the opposition if they enter their territory. Observably, the multiplicities of hate speeches were credited to the former first lady, Patience Jonathan are behind the electoral violence in Rivers State. Put specifically, the hate speeches made it impossible for the APC to campaign in Okrika. Some of the these attacks include the bombing of the APC secretariat in Okrika on January $11^{\text {th }}, 2015$; and the disruption of APC rally in Okrika with explosions and sporabic gunfire on $17^{\text {th }}$ February, 2015. Ezeibe [10] observed that 100 percent of hate speeches credited to Northerners were aimed principally at restoring the position of the president of Nigeria to the North while 56.25 percent of hate speeches credited to southerners aimed at retaining the position in the south. Irrespective of the aim of hate speech, Adibe [1] correctly noted that it is a catalyst for political violence and other sectarian Killings in Nigeria. These hamper's social activities and limits bilateral and diplomatic relationship among Nigerians.

\section{Theoretical Framework}

The theoretical bedrock of this study is the social Identity Theory. The social Identity theory by Tajfel and Turner [30] was developed to explain the psychological basis of inter-group discrimination. It proposes that membership of social groups forms an important part of an individual's identity. They argued that people tend to classify themselves and others into various social categories; this takes the form of ethnicity, religious, affiliation, gender, and age cohort. Turner [30] observed that different social contexts may trigger an individual to think, feel and act on the basis of his personal, family or national level of self. An individual had a number of social identities and any attempt to destroy them could result in social conflict and anti-government activities. Accordingly, members of a group create a sense of in-group feeling. For that reason, they will support their own group at the outlay of other groups.

The rationality or centrality of social identity theory as an underpinning presupposes the desire of groups or persons to compete with other groups or persons for space and the acquisition of available scarce resources (if only the so-called resources are scarce at all). Nnoli [24] agree that individual values, culture, norms and the entire psychological gamut differ. In the light of this, several interests are brought to play out. The differences in value system therefore constitutes a major force in the determination of power play, resource control and ultimately the determination of which group or persons gets what, when and how. The antithesis arising from this level of agitation breeds emerging contradictions and the plausible 
ways of making it thrive is to garnish the same with ethnic coloration (Oyaode, 1994). Ethnicity therefore is used as a tool for the determination of power shifts, public official responsibility, agitations and counter agitations, blackmail, executive propaganda, terrorism, religious uprising, resource allocation, award of contracts, appointment of persons into political offices (whether one is qualified for the job or not). These, among others, are variables that have shaped the direction and locus of the Nigerian politics to date. Ethnicity is nonetheless modeled along the lines of elite competition, and hence, a veritable factor that engenders ethno-religious hate speech and political violence. This scenario is a creation of the elites, who draw upon, distort and sometimes fabricate materials from cultures of the group they wish to represent in order to protect their well-being or existence in order to gain political and economic advantage for their groups as well as for themselves [9]. Thus, Apam [3] argued that the process invariably involves competition and conflict for power, economic benefit and social status between the political elite, class and leadership group within and among different ethnic categories.

In the final analysis, the relevance of the social identity theory is based on its ability to justify how elite greed, abuse of political power, alienation, marginalization and exclusion has engendered ethno-religious hate speech and political violence in Nigeria's fourth republic.

\section{Methodology}

This study examined the relationship between ethno-religious hate speech and political violence in Nigeria's fourth republic. A descriptive survey design was adopted and data was collected via a survey of 600 electorates in south-south zone of Nigeria comprises of Traditional Leaders, Christian, Muslims, Youths and members of Civil Society groups. Data collected were analyzed using Pearson product Moment correlation and Regression Analysis.

\section{Reliability and Validity of the Instrument}

The questionnaire was validated by experts in political science. A pilot study to determine the level of reliability was carried out on 50 electorates in Delta and Edo state who were part of the study within a time interval of two weeks. Cronbach Alpha method was used to establish the internal consistency of the instrument as shown in the table below.

Table 1

Reliability Statistics of Variable

\begin{tabular}{|c|c|c|}
\hline Scale & No. of Items & Cronbach's Alpha \\
\hline Ethno-religious hate speech & 15 & 0.813 \\
\hline Political violence & 18 & 0.798 \\
\hline
\end{tabular}


The results yielded a coefficient of 0.813 and 0.798 , which satisfied the general recommended level of 0.70 for the research indicators (cronbach, 1951). Hence, researchers satisfied both reliability and validity of the scale.

\section{Results and Discussion}

This study examined the relationship between ethno-religious hate speech and political violence in Nigeria's fourth republic. To achieve this, six hundred (600) questionnaires were administered across the south-south geopolitical zone. Out of the 600 questionnaires distributed, 472 questionnaires representing $78.7 \%$ were retrieved as shows in the table below.

\section{Distribution of Questionnaire and Response Rate}

\begin{tabular}{|c|c|c|c|c|}
\hline S/N & South-South State & $\begin{array}{c}\text { Questionnaires } \\
\text { Distributed }\end{array}$ & $\begin{array}{c}\text { Questionnaires } \\
\text { Retrieved }\end{array}$ & Percentage \% \\
\hline 1 & Akwa Ibom & 100 & 63 & 10.5 \\
\hline 2 & Bayelsa & 100 & 86 & 14.3 \\
\hline 3 & Cross Rivers & 100 & 79 & 13.2 \\
\hline 4 & Delta & 100 & 88 & 14.7 \\
\hline 5 & Rivers & 100 & 77 & 12.8 \\
\hline 6 & Edo & 100 & 79 & 13.2 \\
\hline & Total & 600 & 472 & 78.7 \\
\hline
\end{tabular}

Source: Researchers' fieldwork (2018).

Electorates Responses on Whether Ethno-Religious Hate Speech is the Precursor of Political Violence in Nigeria's Fourth Republic

\begin{tabular}{|c|c|}
\hline Category & Percentage ( \%) \\
\hline Strongly agreed & 63.7 \\
\hline Agreed & 32.4 \\
\hline Neither agreed or Disagreed & 3.9 \\
\hline
\end{tabular}

Source: field survey (2018).

Table 3 shows that ethno-religious hate speech is the precursor to political violence in Nigeria's fourth republic. Out of the total respondents, it was observed that $63.7 \%$ strongly agreed and $32.4 \%$ agreed while only $3.9 \%$ of the respondents neither agreed nor disagreed. 
Correlation Matrix

\begin{tabular}{|c|c|c|c|}
\hline Variables & & $\begin{array}{l}\text { Ethno-Religious } \\
\text { Hate speech }\end{array}$ & Political violence \\
\hline $\begin{array}{l}\text { Ethno-Religious } \\
\text { Hate speech }\end{array}$ & Pearson Correlation & 1 & $0.877 * *$ \\
\hline \multirow[t]{2}{*}{ Political Violence } & Sig.(2-tailed) & & .000 \\
\hline & $\mathrm{N}$ & 472 & 472 \\
\hline Political Violence & Pearson Correlation & $0.877 * *$ & 1 \\
\hline \multirow[t]{2}{*}{$\begin{array}{l}\text { Ethno-Religious } \\
\text { Hate Speech }\end{array}$} & Sig. (2-tailed) & .000 & \\
\hline & $\mathrm{N}$ & 472 & 472 \\
\hline
\end{tabular}

**Correlation is significant at 0.01 levels (2-tailted).

Source: Field Survey (2018).

Table 4 shows the correlation between ethno-religious hate speech and political violence in Nigeria's fourth republic. There exists a significant positive high correlation between ethno-religious hate speech and political violence $(\mathrm{r}=.877$, $\mathrm{n}=472, \mathrm{p}<0.01)$. This implies that ethno-religious hate speech has a strong and positive relationship with political violence in Nigeria's fourth republic. This is widely supported by the previous findings of Joel (2013); Bello [7]; Fasakin et al. [11]; Rasaq et al. [27].

\section{Simple Regression Analysis}

The simple linear regression shows $\left(\mathrm{R}^{2}\right)$ value of 0.713 which reveals that ethno-religious hate speech independently accounts for $71.3 \%$ of the variability in political violence in Nigeria's fourth republic. The F. statistics of 138.528 reveals that the model is statistically significant at 0.05 significant level. Therefore, the null hypothesis is rejected. It can thus be concluded that there is a significant effect of ethno-religious hate speech on political violence in Nigeria's fourth republic.

Table 5

Model Summary

\begin{tabular}{|c|c|c|c|c|}
\hline Model & R & R square & Adjusted R Square & Std. Error of the Estimate \\
\hline 1 & $.535^{\mathrm{a}}$ & .713 & .539 & 19.726 \\
\hline
\end{tabular}

a. Dependent variable: political violence.

b.Predictors: (constant), ethno-religious hate speech.

Source: Authors' computation (2018). 
ANOVA $^{\mathrm{A}}$

\begin{tabular}{|c|c|c|c|c|c|c|}
\hline \multicolumn{2}{|c|}{ Model } & Sum of Square & DF & Mean Square & F & Sig. \\
\hline \multirow{3}{*}{1} & Regression & $231-257$ & 1 & 231.257 & & \\
& Residual & $683-312$ & 524 & 138.528 & $.000^{\mathrm{b}}$ \\
& Total & $914-569$ & 525 & 1.736 & & \\
\hline
\end{tabular}

a. Dependent variable: political violence.

b.Predictors: (constant), Ethno-religious hate speech.

Source: Another's computation.

\section{Policy Recommendations}

Based on the empirical and theoretical findings of this study, the following recommendations were made:

1. The culture of impurity that encourages political violence should be shunned by scrupulous enforcement of laws prohibiting political violence and illegal arms trade, possession and use.

2. INEC should rise up to their constitutional responsibility of monitoring activities of political parties so as to enthrone internal democracy in the political parties with strict adherence to their respective constitutions.

3. The civil society organizations should intensify their efforts in the area of civil education so that the citizens can understand the essence of politics, the values of democratic governance and practices, and to eschew ethnic and religious sentiments in political participation.

4. The media organizations and journalists who are morally inclined to ethical journalism should mobilize and conscientize the public through citizenship education to discouraged and confront hate speech and foul Lange online as part of their civic responsibility.

5. Political parties and their agents should shun all forms of electoral and political violence and should embrace peace, order, and discipline as a means of improving democratic institution and deepening democracy.

6. The newspaper organizations should refrain from publishing abusive comments that denigrate individuals or groups on account of race, ethnicity, disability, religion or gender.

7. The politician should conduct their campaign on the basis of political issues such as economic, political, socio-cultural, educational, and healthcare services rather than attack on political opponents or mobilization of ethnic, religious, and regional sentiments. Also there is need to stop overzealous ambition, lost for power, selfishness, voluptuousness, pride, anger, and revenge in Nigeria politics.

8. The winner takes it all syndrome that is the zero sum game is not ideal in our democratic project because it is willful, violent breeding, parochial, discriminatory, elite based, and unethical. 
9. The Nigeria government should be more proactive in ensuring that the antcorruption agencies are more effective and efficient and not mere appendage of the presidency for witch-hunting perceived political opponents.

10. The National Orientation Agency should be made more active in political times, civic and voters' education more important. This as a matter of fact will change Nigerians pessimistic attitude towards politics and governance.

\section{Conclusion}

In summary, it is clear from the above exposition that ethno-religious hate speech is the precursor to political violence. Nigeria's history, its diversity and political lands cape makes it susceptible to ethnic and religious intolerance, which feeds into hate speech. Hate speech directed at gaining political power lead to political violence in Nigeria's fourth republic. The political violence manifest in assault, assassination, acrimony, intimidation, harassment, maiming and killing and consequently these affect the existing social relationship in the society. Therefore, it is the position of this study that creative strategies to confront ethno-religious hate speech will require the cooperation of government, medial and civil society organizations. Also, the National Orientation Agency, which is the foremost agency of government for enlightenment, orientation, political education and mobilization should challenge and re-orient the citizenry on the dangers of ethno-religious hate speech for the survival of the Nigerian nation. This study further conclude that the civil society organizations should be more vigilant and proactive in challenging the obnoxious policies of government to avoid undermining the human right and civil liberties on which democracy stands.

\section{REFERENCES}

[1] Adibe J. Fayose's advert: offensive or hate speech? A Paper Presented at a Round Table on Hate Speech Organize by the Kukah Centre, Abuja. 2015.

[2] Alakali T.T., Faga H.P., Mbursa J. Audience perception of hate speech in Nigeria: implications for morality and Law // International Scientific Journal. 2017. No. 1. Pp. 161-178.

[3] Apam J. The role of governance in the management of ethno-religious conflicts in Nigeria // Nigerian Journal of Political and Administrative Studies. 2011. No. 2(2). Pp. 1-16.

[4] Aver T.T., Nnorom K.C., Targba A. Political violence and its effects on social development in Nigeria // International Journal of Humanities and Social Science. 2013. No. 3(17). Pp. 261-266.

[5] Bagdikian B.H. The media monopoly. Boston: Beacon press, 1997.

[6] Bell J. Restraining the heart less, racist speech and minority rights // Indiana Law Journal. 2009. Vol. 84(3). Pp. 979-983.

[7] Bello A.H. Causes and dynamic of political violence in Nigeria: Islamic views on the solutions // International Journal of Humanities and Social Science Invention. 2013. No. 2(3). Pp. 28-34.

[8] Chaiken S., Eagly A.H. Communication modality as a determinant of message persuasiveness and message comprehensibility // Journal of Personality and Social Psychology. 1978. Vol. 34. No. 4. Pp. 605-614. 
[9] Erunke C.E. Ethnic question and consolidation of Nigeria democratic project: A prognosis. Being a paper presented at a International conference on Democracy and Development in Africa, Organized by the Department of political Science, Nasarawa State University, Keffi. 2011.

[10] Ezeibe C.C. Hate speech and electoral violence in Nigeria. A Paper Submitted to the Department of Political Science, University of Nigeria, Nsukka. 2015.

[11] Fasakin A., Oyero O., Ouesomi K., Okone N. Hate speech and the 2015 general elections in Nigeria // International E-Journal of Advances in Social Sciences. 2017. No. 3(9). Pp. 948-953.

[12] Gurr T. Why men rebel. Princeton: Princeton University press, 1970.

[13] Howell R. Political Snuggery in vogue. Chicago: L and T press Ltd, 2004.

[14] Imobighe T.A. Ethnicity and ethnic conflicts in Nigeria: An overview. Ibadan: Spectrum Books Ltd, 2003.

[15] Joelm J. Ethno-populism and ethno-religious hate speech in Nigeria. 2013. URL: https://www.researchate.net/publication/236268158 (accessed: 17.03.2019).

[16] Judge M., Nel J.A. Psychology and hate speech: A critical and restorative encounter // South African Journal of Psychology. 2013. Vol. 48. No. 1. Pp. 15-20.

[17] Keane D. Addressing the aggravated meeting points of race and religion // Maryland Law Journal of Race, Religion, Gender \& Class. 2006. Vol. 6. Pp. 371-388.

[18] Leader T., Mullen B., Rice D. Complexity and violence in ethno-populisms and exclusion of ethnic out-groups: what puts the hate into hate speech // Journal of Personality and Social Psychology. 1996. Vol. 96. No. 1. Pp. 170-182.

[19] Leets L. Experiencing hate speech: perceptions and responses to anti-Semitism and antigay speech // Journal of Social Issues. 2002. Vol. 58. No. 2. Pp. 341-361.

[20] Maginnis R. Muslim hate in Nigeria: Nigeria Follows violent path of war-stricken Somalia. 2012. URL: http://www.truthandgrace.com/musliminigeria.htm (accessed: 17.03.2019).

[21] Massaro T. Equality and freedom of expression: the hate speech dilemma // William \& Mary Law Review. 1991. No. 2(11). Pp. 1-32.

[22] Mrabure K.O. Counteracting hate speech and the right to freedom of expression in selected jurisdictions // Nnamdi Azikiwe University Journal of International Law and Jurisprudence. 2016. Vol. 7. Pp. 160-169.

[23] Neshkovska S., Trajkova Z. The essentials of hate speech // International Journal of Education. 2017. Vol. 14. No. 1. Pp. 71-80.

[24] Nnoli O. Ethnic Politics in Nigeria. Eungu: Fourth Dimension publishers, 1978.

[25] Orji N., Uzodi N. Post- election violence in Nigeria: Experiences with the 2011 election. Abuja: policy and Legal Advocacy Centre. 2012.

[26] Oyode E. The military and the national question. Kaduna: Arewa House, 1994.

[27] Rasaq A., Udende P., Ibrahim A., Oba L. Media, politics, and hate speech: A critical discourse analysis // E-Academia Journal. 2017. No. 6(1). Pp. 240-252.

[28] Tamuno T.N. The evolution of the Nigerian states. London: Longman publishers, 1972.

[29] Tayfel H., Turner J.C. Social identity and intergroup relations. Cambridge: Cambridge University press, 1985.

[30] Turner J.C. Towards a cognitive redefinition of the social group. Cambridge University Press, 1982.

[31] Ugbechie K. Hate speech is not free speech in Nigeria today. 2017. URL: http://www.nigeroatpday.ng/2017/02/hate speech is not free speech (accessed: 17.03.2019).

[32] Ugunmwuangho S.O., Epelle A. Challenges and solutions to ethno-religious conflicts in Nigeria: case study of the Jos crises // Journal of Sustainable Development in Africa. 2011. Vol. 13. No. 5. Pp. 109-124.

[33] Wikff S. Ethnic conflicts: A global perspective. Oxford: Oxford University press, 2006. 
Information about the author:

Ugo Chuks Okolie - Chartered Institute of Personnel Management of Nigeria (Ikeja, Nigeria); Edo State Study Centre (Benin City, Nigeria). ORCID iD: 0000-0002-0448-2938. (e-mail: ugookolie3@gmail.com)

Eseohe Glory Okoedion - Department of Foreign Language and Literary Studies, University of Nigeria (Nsukka, Nigeria). ORCID iD: 0000-0002-2639-3477.(e-mail: glory.okodion@unn.edu.ng)

Научная статья

\title{
Этно-религиозные ненавистнические речи и политическое насилие в четвертой республике Нигерии
}

\author{
Уго Чукс Околе \\ Чартерный институт управления персоналом в Нигерии, Икея, Нигерия; \\ Государственный учебный ичентр Эдо, Бенин-Сити, Нигерия

\section{Эсеохе Глори Окоедион}

Университет Нигерии, Нсукка, Нигерия

\begin{abstract}
Этно-религиозные ненавистнические высказывания являются предшественником политического насилия в четвертой республике Нигерии. Хотя верно и то, что одним из величайших преимуществ демократических обществ является свобода слова, тем не менее никому не следует позволять по своему усмотрению осуществлять право на свободу слова, уничижая и унижая другого человека. В Нигерии разжигание ненависти перешло в статус стратегии политической кампании и объясняет эскалацию политического насилия в стране. В данном исследовании изучается влияние этно-религиозных ненавистнических речей на публичное насилие в четвертой республике Нигерии. В работе применяется описательные и социологические методы. Данные были собраны путем опроса 600 избирателей в районе Юг-Юг Нигерии. Исследование показало, что в четвертой республике Нигерии существовала реальная и значимая связь между этно-религиозной ненавистью и политическим насилием. В этом документе среди прочего рекомендуется, чтобы политическая кампания в Нигерии была сосредоточена на реализации важнейших национальных проблем, таких как экономические, политические, социальные, культурные, образовательные и медицинские услуги, а не на атаках политических противников или использовании чувств этнических, религиозных и региональных общин.
\end{abstract}

Ключевые слова: ненавистническая речь, политическое насилие, политическая кампания, этно-религиозные группы, Нигерия

\section{Информация об авторах:}

Уго Чукс Околе - Чартерный институт управления персоналом в Нигерии (Икея, Нигерия); Государственный учебный центр Эдо (Бенин-Сити, Нигерия). ORCID iD: 00000002-0448-2938. (e-mail: ugookolie3@gmail.com)

Эсеохе Глори Окоедион - кафедра иностранных языков и литературоведения Университета Нигерии (Нсукка, Нигерия). ORCID iD: 0000-0002-2639-3477. (e-mail: glory. okodion@unn.edu.ng) 